\title{
"Once upon a Time there was..." A Digital World for Junior High School Learners
}

\author{
http://dx.doi.org/10.3991/ijet.v11i03.5370 \\ M. Batsila ${ }^{1}$, Ch. Tsihouridis ${ }^{2}$ \\ 1 Open University, Milton Keynes, United Kingdom \\ ${ }^{2}$ University of Thessaly, Volos, Greece
}

\begin{abstract}
This paper looks into what Junior High School learners think of the Web 2.0 tool "Storyboard" for digital story telling purposes and investigates the extent to which it can enhance their receptive and productive skills of reading and writing in the English language. Fifty one randomly selected students, who created a digital story based on a relevant instructive scenario, and their teachers took part in the research. The quantitatively analyzed teachers' and students' interviews results and learners' post-tests data revealed that the tool is considered very motivating and useful increasing learners' aforementioned English language skills. As learners and teachers indicate "Storyboard" has offered them moments of happiness and joy during their school activities and made their lesson creative and interesting.
\end{abstract}

Index Terms-ICT, digital storytelling, creative writing, instructive scenario

\section{INTRODUCTION}

The rapid development of information and communication technologies and their utilization in the production process, labor, communication and culture has brought radical changes in all areas of human activity. These changes are associated with the emergence of new professional skills (most of which require computer knowledge), challenging traditional businesses and the growing pressure on businesses and organizations to update the knowledge of their employees, both on a technological and organizational or management basis. To properly prepare learners and future employees, education holds the first and predominant role, according to which students and future professionals and citizens must be trained accordingly and therefore teachers need to keep abreast with modern methods and teaching strategies. Moreover, the need to obtain a higher level of training, in order to follow the rapid pace of technological change and adaptability to the new environment, causes the creation of a socalled "knowledge society", which now depends more than ever on the technological knowledge and/or the use of ICT [1]. Research shows that ICT eliminates borders and barriers faster than it can be done naturally [2]. Because of its interactive nature, ICT cover many gaps in the level of students' knowledge, enhancing their learning [3]. They also promote the use of interactive lessons, encourage e-learning and accelerate the teaching and learning of many skills making the lesson more interesting, pleasant and attractive [4], [5]. Meanwhile, they provide both the teacher and the student, with multimedia audio and video images, enhancing learners' interest in learning [6]. Main- ly, however, they offer an authentic environment and many opportunities for learning, especially language learning. For example, learning computer assisted environments CALL are pleasant and very effective at improving the communication skills of students in foreign languages [7], [8]. Also, the digital environment of 2.0 tools has improved the communication skills of the trainees and audiovisual capacity [9], while internet based activities, enhanced communication skills of pupils and increased their interest in learning [10]. Moreover, the integration of new technologies into the curriculum provides strong incentives for learning and reinforces inclusiveness, interaction, and implementation of innovative actions [11]. Finally, the combination of ICT with stories, games, videos and audiobooks attracts students, providing a pleasant audiovisual learning environment [12].

This kind of learning is realized within groups and communities, well supported by the continuously increasing ICT applications, which exploit relevant scenarios for teaching and learning purposes. Instructive scenarios are stories in which learners and teachers play roles like the ones actors play in films and are realized in various phases: a. the activities done by the learners, $b$. the combination of the group members, c. the way each activity is assigned at each group, $d$. interaction and timing of every phase [13]. In order to design an instructive scenario it is important to keep in mind several features such as: 1 . roles, 2 . activities, 3 . educational sources, 4 . tools, 5 . results.

Instructive scenarios need to go through a "scenario creation cycle" in order to develop and take their final form [14]. Additionally, each scenario should be structured based on elements such as an introduction, link to the curriculum, description of its content, teaching goals, activities design, participants' roles and necessary technological resources. Instructive scenarios can form any teaching framework based on various ICT tools aiming at different educational purposes. Digital story telling ICT based teaching techniques can develop learning through instructive scenarios.

There is a big variety of tools for the implementation of digital stories. There are the office systems: Cosy Comic Strip Creator, Camtasia Studio, StoryBoard Artist Studio, Microsoft Photo Story 3, Apple iMovies, Audacity, Adobe Photoshop Elements, PhotoStage Slideshow Software, Adobe Premiere Elements, Microsoft Windows Live Movie Maker, SAM, StoryMat, StoryRooms, KidsRoom, PETS, Scratch, Storytelling Alice, Kid Pix, Kid Works, StoryBook and more. There are also the Web2.0 tools like 
Animoto, Meograph, Prezi, VoiceThread, Flicker, My StoryMaker, Storybird, Lego Comic Builder and more.

Digital story telling process entails the creation of a story based on a scenario, implemented with the help of multimedia usage. It combines narration with a digitized content, comprises videos, sound, images, color and movement, aims at the creation of a story for instructional purposes and it is very creative as a process as it "creates an opportunity to reflect on life and find deep connection with the subject matter of a course or with an out-of-class experience" [15].

Research has shown that digital story telling around the world is an increasing teaching practice with many benefits and challenges [16,17,18,19,20,21,22,23,24,25]: it allows the user/creator of the story to practice skills such as selection, elaboration and decision making of the choice of a topic and content made. It attracts and motivates the learners and supports his/her ability to consolidate new knowledge due to the strong effect of the image and sound. It has been found to boost learners' effort for critical thinking [26], while it presents a potential of regarding student motivation and engagement [27]. Meanwhile its use can enhance problem solving competence and learning achievement [28]. Similarly, digital storytelling has been found to be beneficial for the classroom [29], whereas, its critical socio-educational focus in education has also been emphasized [30].

\section{Rationale For The Present StUdy}

Based on the aforementioned benefits of digital storytelling and driven by the fact that reading and mainly writing are considered rather difficult and boring tasks by learners, the authors decided to use digital storytelling to motivate Junior High School learners towards the practice of reading and writing skills in English following a carefully designed instructive scenario. The authors aimed at investigating whether the use of tools such as "Storyboard", can enhance learners' reading and writing skills and improve their competence in them. Additionally, the aim was to detect learners" opinion on the "Storyboard" tool which was chosen as it is a rather easy tool to use and thus, students could concentrate on the story making and practice of their skills without having to worry about practical matters and spend valuable time on factors such as how to use the specific tool.

\section{THE RESEARCH}

\section{A. Research questions}

Conducting our research with both a quantitative and qualitative method, the research questions were as follows: 1. To what extent has digital storytelling enhanced learners' reading skills competence in English? 2. To what extent has digital storytelling enhanced learners' writing skills competence in English? 3. What is the learners' opinion on digital storytelling?

\section{B. The Sample}

Fifty one second grade Junior High School learners participated in the research aged 13-14 from two different classes, randomly selected. Their level of English was officially supposed to be B1 based on the Common European Framework for Languages. Participants in this research were also the three English teachers that taught the particular classes (all women- two of them taught the first group and the third teacher taught the second group).

\section{Research tools}

Learners' skill competence was measured with the use of the National Foreign Language Exam System (KPG test), which comprises four modules (reading comprehension and language awareness, writing and written mediation, listening comprehension, speaking and oral mediation). KPG is a stabilized test, used to assess learners' skills competence in foreign languages. The maximum possible score at B1 level candidates can gain is 100 . The pass mark for the KPG, as set by law, is 60. Candidates must gain at least $30 \%$ of the maximum possible marks in Modules 1-3; there is no minimum mark required in Module 4, although the marks candidates receive are included in their total score. Thus, this test was used to offer us answers for the first two questions. For the third question we formed a focus group with randomly selected learners who gave their opinion on the specific method and tool (table I).

TABLE I.

KPG EXAM SPECIFICATIONS

\begin{tabular}{|c|c|c|c|c|c|c|c|}
\hline \multirow{2}{*}{$\begin{array}{c}\text { Mod- } \\
\text { ule }\end{array}$} & \multirow{2}{*}{\begin{tabular}{|c|} 
Type of \\
items/tasks
\end{tabular}} & \multirow{2}{*}{\begin{tabular}{|c|} 
Number \\
of \\
items/task \\
$s$
\end{tabular}} & \multirow{2}{*}{$\begin{array}{c}\text { Wei } \\
\text { ghti } \\
\text { ng }\end{array}$} & \multicolumn{2}{|c|}{ Mark } & \multirow{2}{*}{$\begin{array}{c}\text { Time } \\
\text { (minute } \\
\text { s) }\end{array}$} & \multirow{2}{*}{$\begin{array}{c}\text { Text } \\
\text { size } \\
\text { (words) }\end{array}$} \\
\hline & & & & Max & & & \\
\hline \multirow{2}{*}{1} & Choice & 40 & 0.5 & 20 & \multirow{2}{*}{8} & \multirow{2}{*}{65} & \multirow{2}{*}{$\begin{array}{l}700- \\
1000\end{array}$} \\
\hline & Completion & 10 & 0.5 & 5 & & & \\
\hline 2 & $\begin{array}{l}\text { Semi guided } \\
\text { written } \\
\text { production }\end{array}$ & $2-3$ & - & 30 & 9 & 45 & $160-200$ \\
\hline \multirow{2}{*}{3} & Choice & 15 & 1 & 15 & \multirow{2}{*}{8} & \multirow{2}{*}{$15-20$} & \multirow{2}{*}{$\begin{array}{c}\text { Not } \\
\text { defined }\end{array}$} \\
\hline & Completion & 5 & 2 & 10 & & & \\
\hline 4 & $\begin{array}{l}\text { Semi guided } \\
\text { oral produc- } \\
\text { tion }\end{array}$ & 3 & - & 20 & - & $15-20$ & $\begin{array}{c}\text { Not } \\
\text { defined }\end{array}$ \\
\hline \multicolumn{4}{|c|}{$\begin{array}{l}\text { Minimum total grade required for B1 } \\
\text { level certification }\end{array}$} & & 60 & & \\
\hline \multicolumn{4}{|c|}{$\begin{array}{l}\text { Highest possible grade for B1 level } \\
\text { certification }\end{array}$} & 100 & & & \\
\hline
\end{tabular}

All learners however also took a questionnaire in order to provide us with their views on the specific tool. The questionnaire comprised of 7 questions with answers given on a five point Likert scale of 'very much', 'a lot', 'quite', 'a little' and 'not at all'. The questions were designed to draw learners' opinion regarding: easiness of use, attractiveness, appropriateness for this age, interesting sources of images, innovative design, appropriateness for learning purposes, promotion of interest, active participation, skills improvement and pleasant environment. Semiconstructed interviews were also conducted with the participant teachers. For validity purposes, the design of the questions was based on the stages and principles of interview questions design [31]. However, a pilot interview was also conducted with a teacher in order to reformulate the questions if necessary. The duration of the interviews ranged between 21 to 32 minutes. All three interviews took place in the schools' libraries at times that were convenient for the teachers so as to feel free and relaxed (during their free hour). All three teachers were explained that they could withdraw any time they wished so and that 
they could have a copy of the transcription themselves if they wanted. The questions were classified in three categories: 1. Working profile of the participants, 2.Their opinion on the "Storyboard" tool, 3.Their opinion on its effectiveness in the teaching process. Finally, the researchers were present during the research stages taking notes of the whole process.

\section{Research stages}

The study took place in six successive phases and lasted for two months:

$1^{\text {st }}$ phase (2 hours): As a first step, two Junior High School classes were randomly selected in the research location, in October 2014. After having received the state permission to proceed with the research, parents' and principals' consent, the researchers proceeded with the next phase.

$2^{\text {nd }}$ phase (2 hours): All learners took a pre-reading and writing KPG test to detect their level in English. The test was taken the same day by both participant groups.

$3^{\text {rd }}$ phase (2 hours): Learners were explained the basic steps of the tool with examples so as to familiarize them with its use.

$4^{\text {th }}$ phase (8 hours): A series of eight lessons where the students implemented the given scenario followed. With the help of their teachers, learners formed groups and created their own stories based on thematic areas of their syllabus and curriculum. The scenario was based on a project about 'bullying' and learners had to create their own stories through which they could express their views, sending at the same time the right messages against this violent phenomenon.

$5^{\text {th }}$ phase (2 hours): By the end of the intervention, learners took a post KPG reading and writing test to detect the level of improvement. The test did not have the same tasks but similar ones and level as the previous one. The test was taken the same day or the following by all students, who answered it with exactly the same time allocated by the test specifications. They also took a questionnaire and participated in a focus group discussion.

$6^{\text {th }}$ phase: Three weeks after the second test, learners took a similar follow up test, again of the same level to determine any differentiation in their answers.

\section{RESUlTS}

\section{A. Method of processing the experimental data}

Analysis of the overall data collected followed. In addition to the multiple choice questions of the questionnaire, content analysis was performed on the interview data, something that also happened for the open-type questions, which ended-up being classified into broad categories, for the purpose of being used in a form of quantitative data, and to extract any real information contained in them.

\section{B. Statistical analysis-data analysis}

For the checking of statistical hypotheses we use the aforementioned SPSS statistical package. The checking of the statistical hypotheses aims at verifying or rejecting a hypothesis. In order to exploit the sample data we formulate two hypotheses: a) null hypothesis Ho which is based on the acceptance that there is not a statistical significant effect of the independent sample on the dependent and b) alternative hypothesis $\mathrm{H} 1$ which expresses the opposite of the null. A statistically significant difference, smaller than an acceptable limit of significance $(5 \%, 1 \%$ or $1 \%$ ) means the rejection of the null hypothesis and the acceptance of the null $[1,2]$. In the present research we set the level of significance at $5 \%$. The use of the appropriate checking criterion (parametric or not) of the research hypothesis depends mainly on the plan of the research, the commitment of the level of the data and the type of the indexes of the measurement of the variables.

In this research the appropriate statistical criterion is the parametric $t$ criterion for depended samples that fulfil the conditions of its use. The research hypotheses are:

Ho: Null hypothesis: Students' performance remained the same after the teaching intervention

H1: Alternative hypothesis: Students' performance did not remain the same after the teaching intervention

It should be noted that there is no attempt to predict which group displays the best or worse performance. Therefore a two-sided checking hypothesis is formulated. The results of the SPSS statistical package are presented below.

\section{Data analysis methodology}

The results of the statistical analysis with the use of SPSS statistical package are given on the following table of descriptive statistics:

TABLE II.

MEAN PER Question

\begin{tabular}{|c|c|c|c|}
\hline \multicolumn{4}{|c|}{ Descriptive Statistics } \\
\hline & $\mathbf{N}$ & & \\
\hline & Statistic & Statistic & Std. Error \\
\hline Q1. Is the tool easy to use? & 51 & 4,16 & ,144 \\
\hline Q2. Is the tool attractive? & 51 & 3,69 & ,144 \\
\hline Q3. Is it appropriate for your age? & 51 & 3,39 & , 168 \\
\hline $\begin{array}{l}\text { Q4. Does it have an interesting } \\
\text { source of images? }\end{array}$ & 51 & 3,82 & 187 \\
\hline Q5. Is it innovative in its design? & 51 & 3,53 & ,138 \\
\hline $\begin{array}{l}\text { Q6. Is it appropriate for learning } \\
\text { purposes? }\end{array}$ & 51 & 3,82 & ,172 \\
\hline $\begin{array}{l}\text { Q7a. Give reasons as to why (if at } \\
\text { all) you think the tool is can help } \\
\text { you with your lessons-Promotes } \\
\text { students' interest }\end{array}$ & 51 & 3,78 & , 169 \\
\hline $\begin{array}{l}\text { Q7b. Give reasons as to why (if at } \\
\text { all) you think the tool is can help } \\
\text { you with your lessons-Promotes } \\
\text { active participation }\end{array}$ & 51 & 3,71 & ,126 \\
\hline $\begin{array}{l}\text { Q7c. Give reasons as to why (if at } \\
\text { all) you think the tool is can help } \\
\text { you with your lessons-Facilitates } \\
\text { skills improvement }\end{array}$ & 51 & 3,49 & ,152 \\
\hline $\begin{array}{l}\text { Q7d. Give reasons as to why (if at } \\
\text { all) you think the tool is can help } \\
\text { you with your lessons-Offers a } \\
\text { pleasant learning environment }\end{array}$ & 51 & 3,98 & 162 \\
\hline Valid N (listwise) & 51 & & \\
\hline
\end{tabular}

The following chart presents the averages with the error bars per question: 


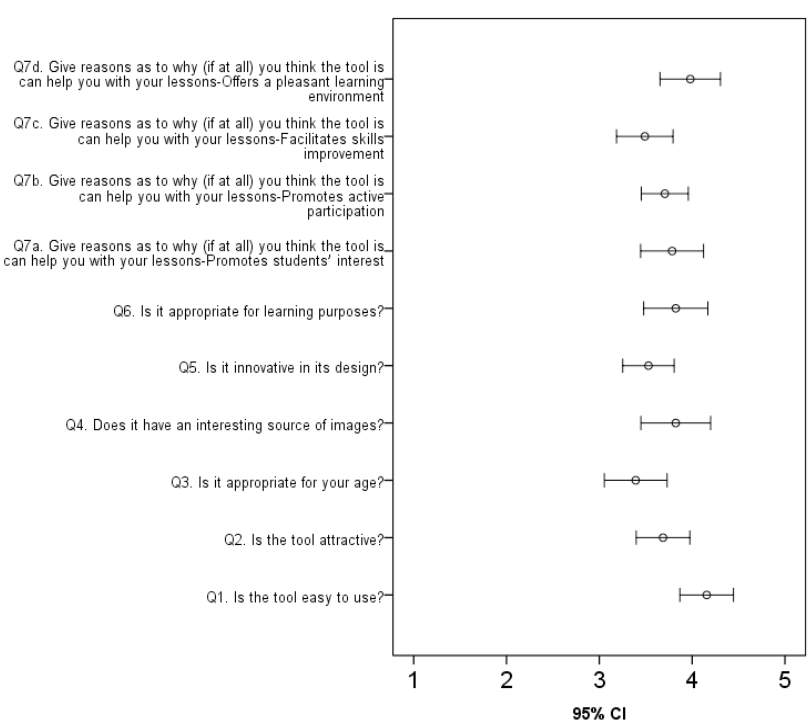

Figure 1. Error chart per question

\section{1) Question 1: Is the tool easy to use?}

Students' answers are recorded on the following table of descriptive statistics as they resulted from the SPSS analysis:

TABLE III.

Q1. IS THE TOOL EASY TO USE?

\begin{tabular}{|ll|c|c|c|}
\hline & Frequency & $\begin{array}{c}\text { Valid } \\
\text { Percent }\end{array}$ & $\begin{array}{c}\text { Cumulative } \\
\text { Percent }\end{array}$ \\
\hline Valid & not at All & 1 & 2,0 & 2,0 \\
& a Little & 4 & 7,8 & 9,8 \\
Quite & 5 & 9,8 & 19,6 \\
a Lot & 17 & 33,3 & 52,9 \\
Very Much & 24 & 47,1 & 100,0 \\
Total & 51 & 100,0 & \\
\hline
\end{tabular}

Based on the above table and the general table I we can see that a large percentage of students consider that tool is easy in its use "Very Much" $47,1 \%$ or "a lot" on the test scale, that is, $33,3 \%$.

The answers to the specific question are also shown on the following frequency diagram:

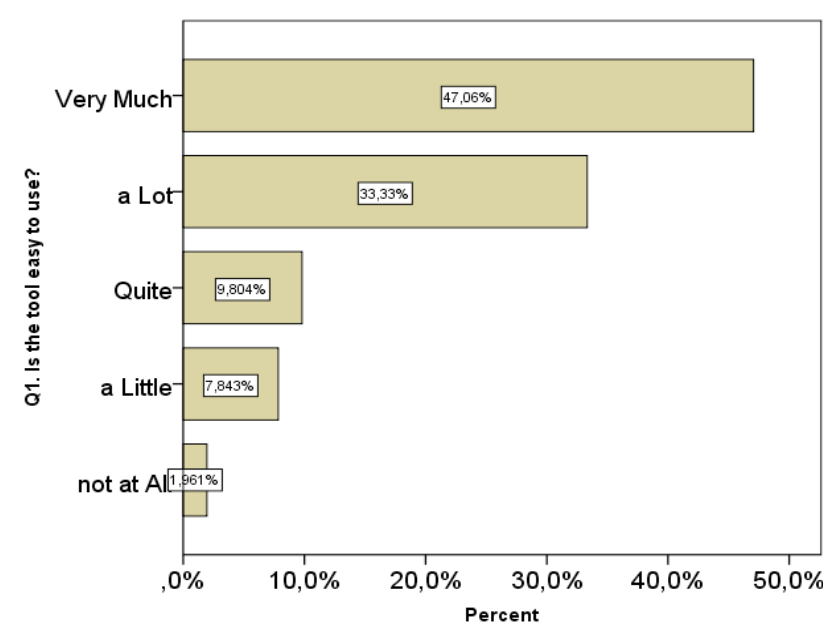

Figure 2. Ease of Use
2) Question 2: Is the tool attractive?

Students' answers are recorded on the following table of descriptive statistics as they resulted from the SPSS analysis:

TABLE IV.

Q2. IS THE TOOL ATTRACTIVE?

\begin{tabular}{|ll|c|c|c|}
\hline & Frequency & $\begin{array}{c}\text { Valid } \\
\text { Percent }\end{array}$ & $\begin{array}{c}\text { Cumulative } \\
\text { Percent }\end{array}$ \\
\hline Valid & not at All & 2 & 3,9 & 3,9 \\
& a Little & 5 & 9,8 & 13,7 \\
Quite & 10 & 19,6 & 33,3 \\
a Lot & 24 & 47,1 & 80,4 \\
Very Much & 10 & 19,6 & 100,0 \\
Total & 51 & 100,0 & \\
\hline
\end{tabular}

Based on the above table and the general table I we can see that a large percentage of students consider that the tool is attractive "Very Much" $19,6 \%$ or "a lot" on the test scale, that is, $47,1 \%$.

The answers to the specific question are also shown on the following frequency diagram:

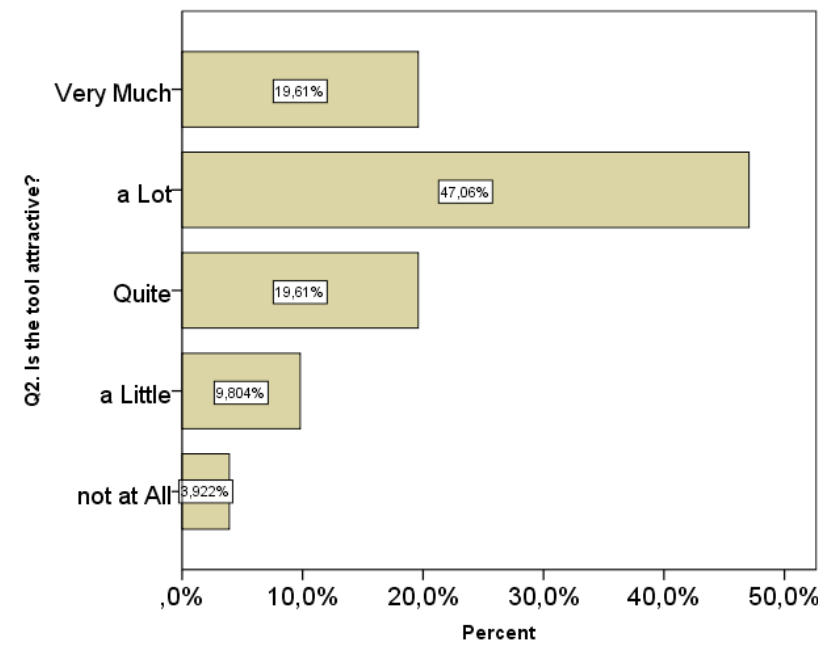

Figure 3. Is the tool attractive?

\section{3) Question 3: Is it appropriate for your age?}

Students' answers are recorded on the following table of descriptive statistics as they resulted from the SPSS analysis:

TABLE V.

Q3. IS IT APPROPRIATE FOR YOUR AGE?

\begin{tabular}{|cl|c|c|c|}
\hline & Frequency & $\begin{array}{c}\text { Valid } \\
\text { Percent }\end{array}$ & $\begin{array}{c}\text { Cumulative } \\
\text { Percent }\end{array}$ \\
\hline Valid & not at All & 4 & 7,8 & 7,8 \\
& a Little & 9 & 17,6 & 25,5 \\
Quite & 10 & 19,6 & 45,1 \\
a Lot & 19 & 37,3 & 82,4 \\
Very Much & 9 & 17,6 & 100,0 \\
Total & 51 & 100,0 & \\
\hline
\end{tabular}


Based on the above table and the general table I we can see that a large percentage of students consider that the tool is appropriate for their age " a Lot" $37,3 \%$ or "Quite" on the test scale, that is, 19,6\%.

The answers to the specific question are also shown on the following frequency diagram:

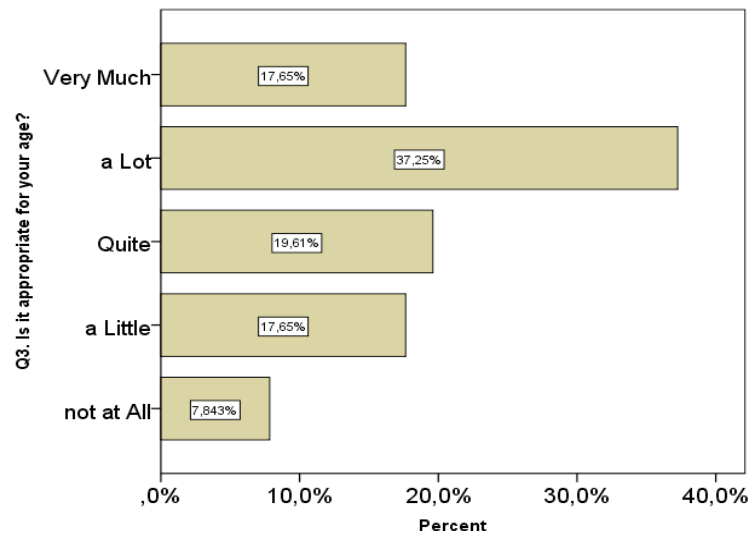

Figure 4. Appropriateness of age

\section{4) Question 4: Does it have an interesting source of images?}

Students' answers are recorded on the following table of descriptive statistics as they resulted from the SPSS analysis:

TABLE VI

Q4. Does IT Have AN INTERESTING SOURCE Of IMAGES?

\begin{tabular}{|cl|c|c|c|}
\hline & Frequency & $\begin{array}{c}\text { Valid } \\
\text { Percent }\end{array}$ & $\begin{array}{c}\text { Cumulative } \\
\text { Percent }\end{array}$ \\
\hline Valid & not at All & 4 & 7,8 & 7,8 \\
& a Little & 7 & 13,7 & 21,6 \\
& Quite & 5 & 9,8 & 31,4 \\
a Lot & 13 & 25,5 & 56,9 \\
Very Much & 22 & 43,1 & 100,0 \\
Total & 51 & 100,0 & \\
\hline
\end{tabular}

Based on the above table and the general table I we can see that a large percentage of students consider that the tool has an interesting source of images "Very Much" $43,1 \%$ or "a Lot" on the test scale, that is, $25,5 \%$.

The answers to the specific question are also shown on the following frequency diagram:

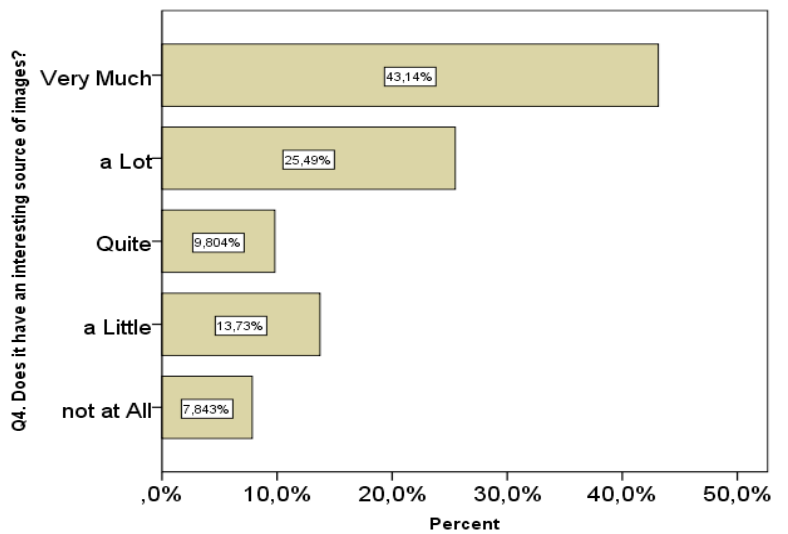

Figure 5. Interesting source of images
5) Question 5: Is it innovative in its design?

Students' answers are recorded on the following table of descriptive statistics as they resulted from the SPSS analysis:

TABLE VII

Q5. IS IT INNOVATIVE IN ITS DESIGN?

\begin{tabular}{|ll|c|c|c|}
\hline & Frequency & $\begin{array}{c}\text { Valid } \\
\text { Percent }\end{array}$ & $\begin{array}{c}\text { Cumulative } \\
\text { Percent }\end{array}$ \\
\hline Valid & not at All & 2 & 3,9 & 3,9 \\
& a Little & 5 & 9,8 & 13,7 \\
& Quite & 15 & 29,4 & 43,1 \\
a Lot & 22 & 43,1 & 86,3 \\
Very Much & 7 & 13,7 & 100,0 \\
Total & 51 & 100,0 & \\
\hline
\end{tabular}

Based on the above table and the general table I we can see that a large percentage of students consider that the tool is innovative in its design "a Lot" $43,1 \%$ or "Quite" on the test scale, that is, $29,4 \%$.

The answers to the specific question are also shown on the following frequency diagram:

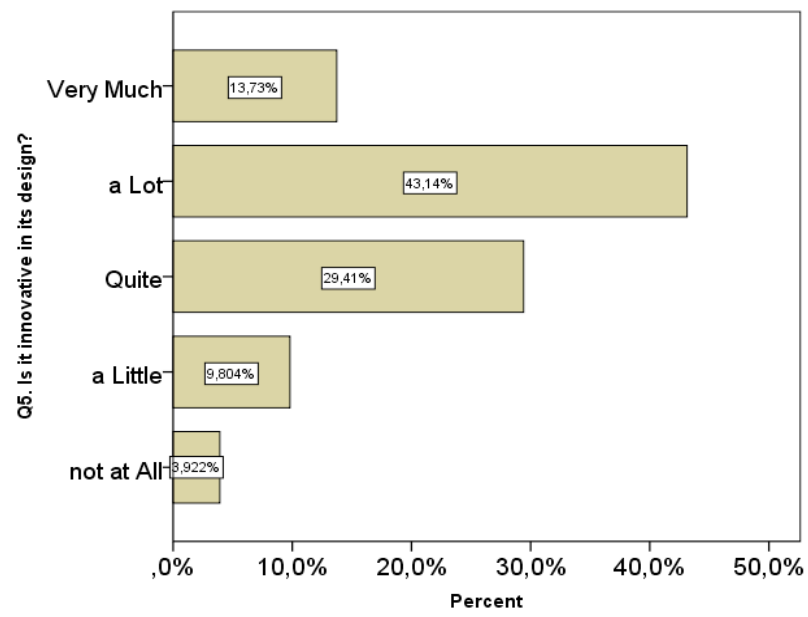

Figure 6. Innovation of design

\section{6) Question 6: Is it appropriate for learning} purposes?

Students' answers are recorded on the following table of descriptive statistics as they resulted from the SPSS analysis:

TABLE VIII.

Q6. IS IT APPROPRIATE FOR LEARNING PURPOSES?

\begin{tabular}{|cl|c|c|c|}
\hline & Frequency & $\begin{array}{c}\text { Valid } \\
\text { Percent }\end{array}$ & $\begin{array}{c}\text { Cumulative } \\
\text { Percent }\end{array}$ \\
\hline Valid & not at All & 3 & 5,9 & 5,9 \\
& a Little & 4 & 7,8 & 13,7 \\
Quite & 13 & 25,5 & 39,2 \\
a Lot & 10 & 19,6 & 58,8 \\
Very Much & 21 & 41,2 & 100,0 \\
Total & 51 & 100,0 & \\
\hline
\end{tabular}


Based on the above table and the general table I we can see that a large percentage of students consider that the tool is appropriate for learning purposes "Very Much" $41,2 \%$ or "Quite" on the test scale, that is, $25,5 \%$.

The answers to the specific question are also shown on the following frequency diagram:

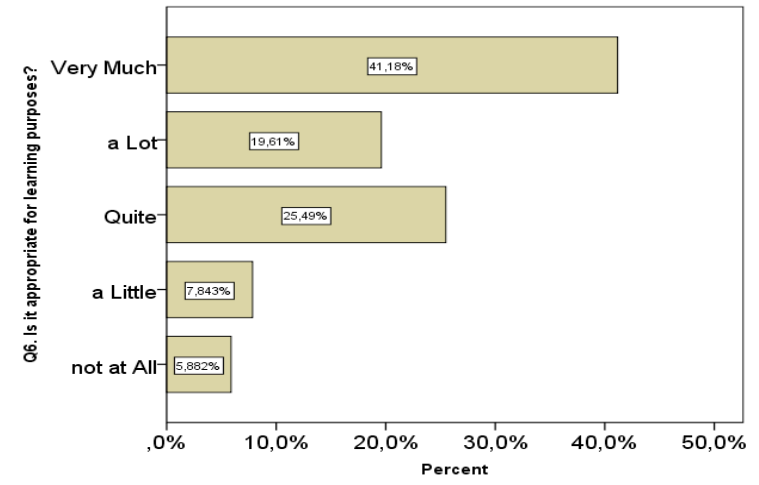

Figure 7. Appropriateness for learning purposes

\section{7) Question 7: Give reasons as to why (if at all) you} think the tool can help you with your lessons.

7a) Promotes students' interest

Students' answers are recorded on the following table of descriptive statistics as they resulted from the SPSS analysis:

TABLE IX.

Q7A. REASONS AS To Why (IF AT ALL) You THINK THE TOOL CAN HELP YOU WITH YOUR LESSONS - PROMOTES STUDENTS' INTEREST

\begin{tabular}{|cl|c|c|c|}
\hline & Frequency & $\begin{array}{c}\text { Valid } \\
\text { Percent }\end{array}$ & $\begin{array}{c}\text { Cumulative } \\
\text { Percent }\end{array}$ \\
\hline \multirow{2}{*}{ Valid } & not at All & 3 & 5,9 & 5,9 \\
& a Little & 5 & 9,8 & 15,7 \\
& Quite & 10 & 19,6 & 35,3 \\
a Lot & 15 & 29,4 & 64,7 \\
Very Much & 18 & 35,3 & 100,0 \\
Total & 51 & 100,0 & \\
\hline
\end{tabular}

Based on the above table and the general table I we can see that a large percentage of students consider that the tool promotes students' interest "Very Much" 35,3\% or "a Lot" on the test scale, that is, $29,4 \%$.

The answers to the specific question are also shown on the following frequency diagram:

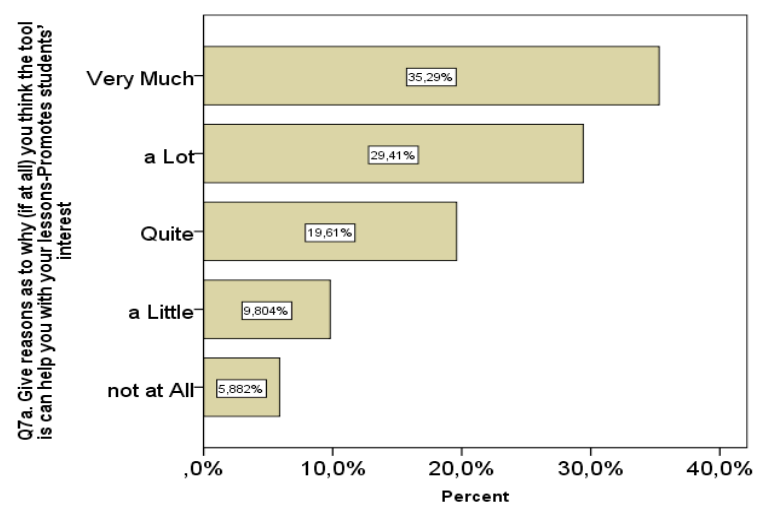

Figure 8. Give reasons as to why (if at all) you think the tool can help you with your lessons-Promotes students' interest 7b) Promotes students' active participation

Students' answers are recorded on the following table of descriptive statistics as they resulted from the SPSS analysis:

TABLE X.

Q7B. REASONS AS TO WHY (IF AT ALL) YOU THINK THE TOOL CAN HELP YOU WITH Your LESSONS - Promotes STUDENTS’ ACTIVE PARTICIPATION

\begin{tabular}{|cl|c|c|c|}
\hline & Frequency & $\begin{array}{c}\text { Valid } \\
\text { Percent }\end{array}$ & $\begin{array}{c}\text { Cumulative } \\
\text { Percent }\end{array}$ \\
\hline Valid & not at All & 5 & 9,8 & 9,8 \\
& a Little & 15 & 29,4 & 39,2 \\
Quite & 21 & 41,2 & 80,4 \\
a Lot & 10 & 19,6 & 90,8 \\
Very Much & 5 & 9,8 & 100,0 \\
Total & 51 & 100,0 & \\
\hline
\end{tabular}

Based on the above table and the general table I we can see that a large percentage of students consider that the tool promotes students' active participation "Quite" $41,2 \%$ or "a Little" on the test scale, that is, $29,4 \%$.

The answers to the specific question are also shown on the following frequency diagram:

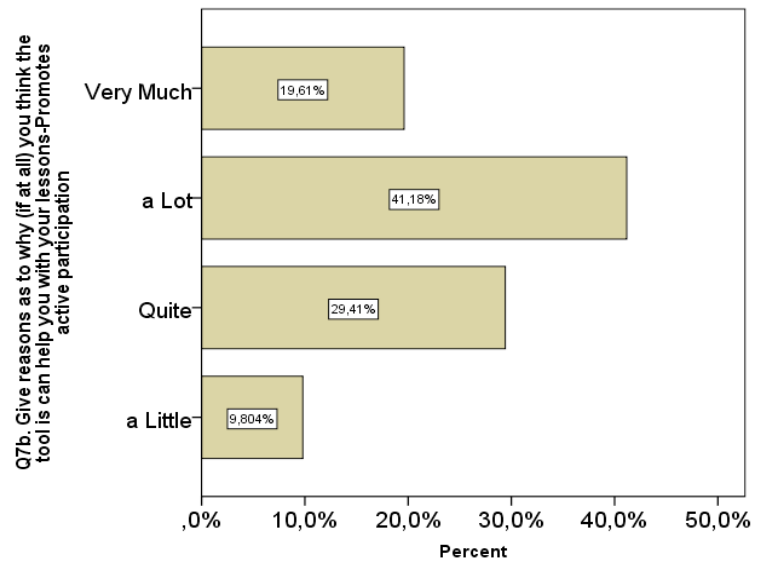

Figure 9. Give reasons as to why (if at all) you think the tool can help you with your lessons-Promotes students' active participation

\section{7c) Facilitates skills-improvement}

Students' answers are recorded on the following table of descriptive statistics as they resulted from the SPSS analysis:

TABLE XI.

Q7C. REASONS As To WHY (IF AT ALL) YOU THINK THE TOOL CAN HELP YOU WITH YOUR LESSONS - FACILITATES SKILLS IMPROVEMENT

\begin{tabular}{|ll|c|c|c|c|}
\hline & Frequency & Percent & $\begin{array}{c}\text { Valid } \\
\text { Percent }\end{array}$ & $\begin{array}{c}\text { Cumula- } \\
\text { tive Per- } \\
\text { cent }\end{array}$ \\
\hline Valid & not at All & 3 & 1,9 & 5,9 & 5,9 \\
& a Little & 8 & 5,0 & 15,7 & 21,6 \\
Quite & 7 & 4,3 & 13,7 & 35,3 \\
a Lot & 27 & 16,8 & 52,9 & 88,2 \\
Very Much & 6 & 3,7 & 11,8 & 100,0 \\
Total & 51 & 31,7 & 100,0 & \\
\hline
\end{tabular}


Based on the above table and the general table I we can see that a large percentage of students consider that the tool facilitates skills improvement "a Lot" 52,9\%.

The answers to the specific question are also shown on the following frequency diagram:

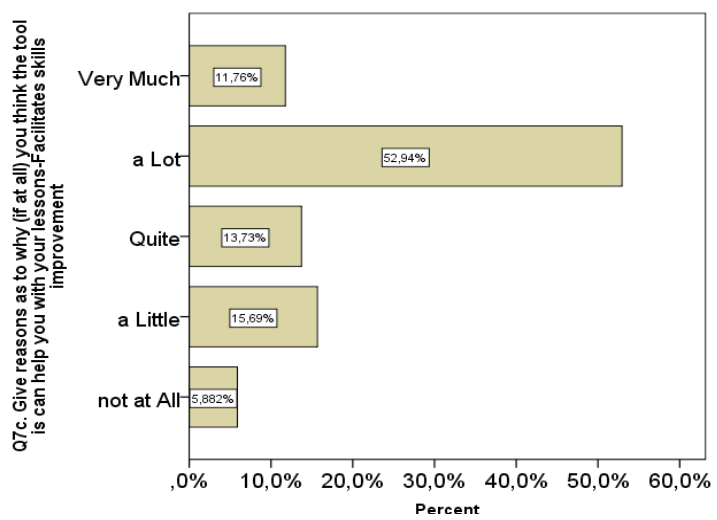

Figure 10. Give reasons as to why (if at all) you think the tool can help you with your lessons-Facilitates skills improvement

\section{7d) Offers a pleasant learning environment}

Students' answers are recorded on the following table of descriptive statistics as they resulted from the SPSS analysis:

TABLE XII

Q7D. REASONS As TO WHY (IF AT ALL) YOU THINK THE TOOL CAN HELP YOU WITH YOUR LESSONS - OFFERS A PLEASANT LEARNING ENVIRONMENT

\begin{tabular}{|ll|c|c|c|}
\hline & Frequency & $\begin{array}{c}\text { Valid } \\
\text { Percent }\end{array}$ & $\begin{array}{c}\text { Cumulative } \\
\text { Percent }\end{array}$ \\
\hline Valid & not at All & 2 & 3,9 & 3,9 \\
& a Little & 5 & 9,8 & 13,7 \\
& Quite & 7 & 13,7 & 27,5 \\
a Lot & 15 & 29,4 & 56,9 \\
Very Much & 22 & 43,1 & 100,0 \\
Total & 51 & 100,0 & \\
\hline
\end{tabular}

Based on the above table and the general table I we can see that a large percentage of students consider software offers a pleasant learning environment "Very Much" $43,1 \%$ or "a Lot" on the test scale, that is, $29,4 \%$.

The answers to the specific question are also shown on the following frequency diagram:

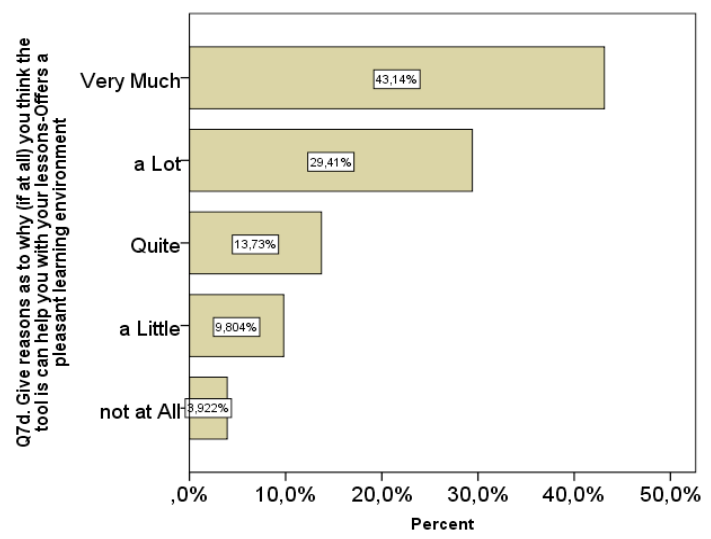

Figure 11. Give reasons as to why (if at all) you think the tool can help you with your lessons-Offers a pleasant learning environment

\section{Checking the effectiveness of the instructive tool in} pre and post-testing

With the use of the SPSS statistical package and the ttest statistical criterion of independent samples we have the following (table XIII):

TABLE XIII.

RESUltS OF THE T CRITERION FOR DEPENDED SAMPLES AT PRE/POST TESTING

Paired Sample Correlations

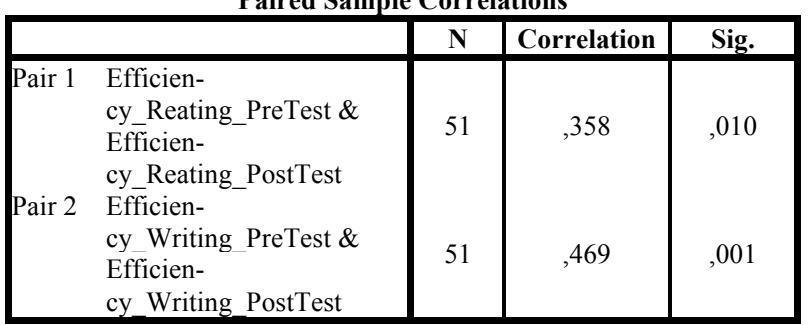

Paired Samples Test

\begin{tabular}{|c|c|c|c|c|c|c|c|}
\hline & & \multicolumn{3}{|c|}{ Paired Differences } & \multirow[b]{2}{*}{$\mathrm{t}$} & \multirow[b]{2}{*}{$\mathrm{df}$} & \multirow[b]{2}{*}{$\begin{array}{l}\text { Sig. (2- } \\
\text { tailed) }\end{array}$} \\
\hline & & Mean & $\mathrm{SD}$ & $\begin{array}{l}\text { Std. } \\
\text { Error } \\
\text { Mean }\end{array}$ & & & \\
\hline $\begin{array}{c}\text { Pair } \\
1\end{array}$ & $\begin{array}{c}\text { Efficien- } \\
\text { cy_Reating_P } \\
\text { reTest - Effi- } \\
\text { cien- } \\
\text { cy_Reating_P } \\
\text { ostTest }\end{array}$ & 19,62 & $\begin{array}{r}9,1 \\
3\end{array}$ & 1,27 & $-15,34$ & 50 &, 000 \\
\hline $\begin{array}{c}\text { Pair } \\
2\end{array}$ & $\begin{array}{c}\text { Efficien- } \\
\text { cy_Writing_P } \\
\text { reTest - Effi- } \\
\text { cien- } \\
\text { cy_Writing_P } \\
\text { ostTest }\end{array}$ & 25,37 & $\begin{array}{r}8,2 \\
8\end{array}$ & 1,16 & $-21,85$ & 50 &, 000 \\
\hline
\end{tabular}

Based on $t$ criterion and the above table, for all possible comparisons at pre and post-test, the result is statistically significant $(p<0,05)$ and leads to the acceptance of the alternative hypothesis, that is the performance of the students in all instructive aims (Reading and Writing has improved significantly after the teaching intervention ( $\mu \mathrm{o}$ $\neq \mu 1$ ). The improvement at post testing for writing is at $19,62 \%( \pm 9,13 \%)$ and for reading it comes to $25,37 \%( \pm 8,28 \%)$ compared to the pre-test performances

We come to the same conclusion using a chart (error chart 1) with confidence intervals $95 \%$ of the average for every group.

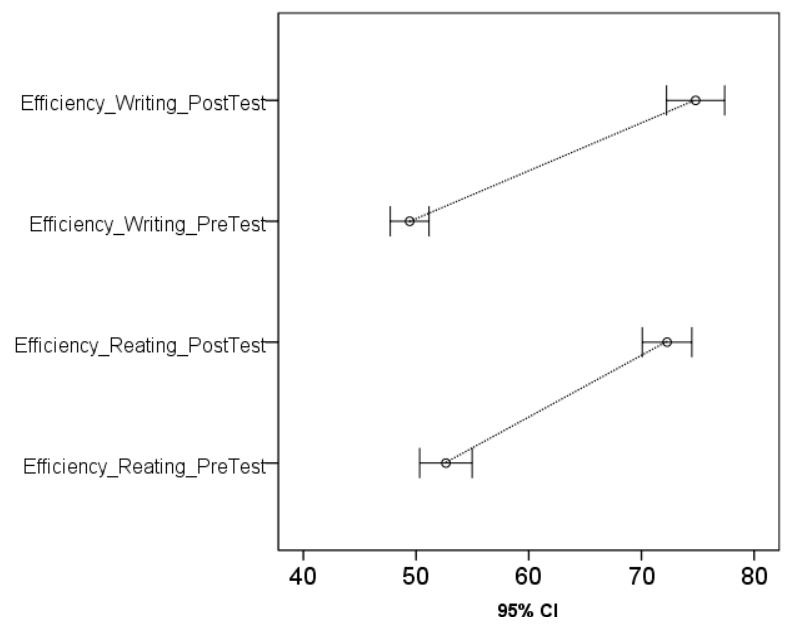

Figure 12. Error chart for the participant groups at pre/post tests 
From the above chart we can support the fact that there is a statistically significant difference between pre-test and post-test for the comparisons of the groups as there are no corresponding overlaps.

\section{E. Teachers' Interviews results}

\section{Teachers' working profile}

To begin with, and for validity purposes, the results are accompanied by extracts from the teachers' answers. Meanwhile, for anonymity purposes teachers are referred to as T1, T2 and T3. All three teachers had a teaching experience that ranged between 8 to 17 years of teaching in public schools. They all taught at Junior High Schools but two of them had also taught in Senior High Schools in the past as well. They had all been trained on the use of Web 2.0 schools by their school advisors and were very positive about their use in the classroom.

\section{Teachers' opinion on the "storyboard" tool}

According to the teachers, the specific tool was found to be innovative and therefore interesting "I like its design ... it is not like any other tool I used in the classroom..." T3. As they admitted "Storyboard" was rather easy for the learners to use and did not demand any specialized knowledge either on their behalf or on behalf of the learners "They could all do it... right from the start... I didn't have to worry about spending more time..." T1. The teachers believed that it is a pleasant tool due to the great variety of images it can offer. They also admitted they liked the fact that it is an appropriate tool for this age and therefore they did not have to worry about any complaints on behalf of the parents or the school principal regarding any inappropriate material "You know, if it's not what it should be, I mean good for this age..., you understand... we are concerned... with parents... the school... we have to be careful what we use... but not with this..."T1. Finally, they expressed their enthusiasm as regards its capability to activate learners and this, as they revealed, was a "miracle" as their class was "awake" and energetic instead of bored and passive in the teaching process "You saw them... you were there... really, I don't remember the last time I saw them being so lively... ’T2.

\section{Teachers' opinion on the "storyboard" tool effectiveness}

Based on the teachers" answers, "Storyboard" was found to be a very helpful tool for their teaching aims enhancing learners' English language skills "It really served its purpose, didn't it?.. 'T3. The teachers were very surprised to see that while writing especially was considered a rather boring task for the learners, it was converted to a fun time during which learners expressed their creativity and skills "I think they will be asking me to work on it all the time from now on! I don't mind really! I am glad they enjoy writing!... ’T1. In addition, as teachers argued, the specific tool promoted interactivity among learners while working on their projects, trying to communicate and exchange their ideas and work "When you see them going from desk to desk, sometimes it's panicking... but this is learning, isn't it? 'T3. They also mentioned that they found the tool to be of particular help to weak learners who at their own pace and time, though part of their groups, could feel important and useful doing something that could understand and together enjoy, drawing happi- ness out of it and gaining cognitive improvement "I feel thankful... [Students xx] loved it, I know they are so shy.... They even made friends like this... it's really so encouraging...'T2. Finally, they expressed their wish to have a more flexible syllabus which can give them the opportunity to implement more digital stories like this "Our only concern is how to find more time... with the syllabus and all...'”2.

\section{DISCUSSION AND CONCLUSIONS}

In this paper we described our effort to investigate learners' opinion regarding the "storyboard" tool for the creation of digital story telling. Learners' questionnaire results revealed that they considered the tool easy to use and attractive with a good source of images. To their mind, it is a motivational tool appropriate for learning purposes. Post-tests revealed that the tool enhanced learners' reading and writing skills. Meanwhile, the focus group results showed that learners found the process really exciting, motivating and pleasant. They also stressed the fact that they liked working in groups, putting their creative ideas to practice. What really surprised us was the students' eager anticipation to use this technique in their classes again. Another fact which also amazed us was their different perspective towards writing. As they admitted, they did not find it boring anymore and they even made suggestions to their teacher regarding relevant activities and/or stories to implement. They even suggested taking part in a contest which showed their great enthusiasm and change of attitude towards writing and reading skills. Similarly, teachers' interviews results revealed their positive attitude towards its use. As they argued, "Storyboard" was an effective tool to use in the classroom for teaching purposes and skills enhancement and particularly stressed the fact that converted their learners from bored students to active participants. Last, they admitted that the tool proved to be very effective for rather weak learners who finally found their place in the group and gained their self- confidence.

We would like to add that this was just a first effort to investigate the effectiveness of this tool and technique. As a next step we aim at a bigger sample as well as at a comparative study between this method and the traditional skills writing and reading teaching practices in order to verify our results and shed more light into the issue. Finally we would like to say that teachers' greatest concern is how to best implement their ideas for effective teaching and learning results. Students of today are not the passive participants of the past any more but the digital young experts of today and tomorrow who many a time precede their own teachers. Moreover, new technologies offer educators a vast source of ideas and solutions for their teaching practices. In this great challenge it is extremely important for us, teachers, to find ways to motivate learners, offer them the best of knowledge and train them to become successful citizens of tomorrow; and if, in the end of this long but so exciting journey, we are able to leave the classroom with this happy feeling of having fulfilled our goals and if the last thing we have in our minds is our learners' big happy smiles and exciting looks on their faces, then we have probably managed to be successful and we should be very happy and proud about it. 


\section{REFERENCES}

[1] K. Morrow, "Principles of Communicative Methodology", In K. Johnson and K. Morrow (Eds.), Communication in the Classroom. London: Longman, 1981, pp. 59-66, 1981.

[2] Directorate General of Education and Culture, The Impact of New Information Technologies and Internet on the Teaching of Foreign Languages and on the Role of Teachers of a Foreign Language, $I C C, 2010$

[3] G. Kress, Literacy in the New Media Age, London: Routledge, 2003 http://dx.doi.org/10.4324/9780203164754

[4] R. J. Samuel, and A. B. Zaitun, Do Teachers have Adequate ICT Resources and the Right Skills in Integrating ICT Tools in the Teaching and Learning of English Language in Malaysian Schools? EJISDC, Vol. 29, (2), pp. 1-15, 2007.

[5] M. Rahimi, and S. Yadollahi, ICT Use in EFL Classes: A Focus on EFL Teachers' Characteristics, World Journal of English Language, (October 2011) Vol. 1 (2), pp. 1729, 2006

[6] A. Padurean, and M. Margan, Foreign Language Teaching Via ICT. Revista de Informatica Sociala. Vol. 6, (12), (December 2009), pp. 97-101, 2009

[7] L. Zhihong, H. Leijuan, and H. Xiaohui, A research on a studentcentered teaching model in an ICT-based English audio-video speaking class, International Journal of Education and Development using Information and Communication Technology (IJEDICT), Vol. 6 (3), pp. 101-123, 2010

[8] M. S. Gomez, Using web resources to support teachers and students with the teaching and practice of listening comprehension, Encuentro 19, pp. 2031, 2010

[9] A. Rico, M. M. Jose, and M. Garcia, The Use of ICTs to Improve Communicative Skills in a Bilingual Context: an Educational Project of the Spanish Ministry of Education in Melilla. International Conference: ICT for Language Learning, 4th edition, 2011

[10] B. N. Bassma, The Impact of Using Technology in Teaching English as a Second Language, English Language and Literature Studies, Vol. 3 (1), 111-116, 2013

[11] S. Leone, The use of new technologies in advanced Italian classes. Proceedings of the Emerging Technologies Conference, University of Wollongong, (June 2008), pp.18-21, 2008

[12] M. Manasreh, ICT and the Teaching of English in Qatar: Improving Practice Through Action Research H Inquiry. Part of a dissertation: ICT and the teaching of English in Quatar. An initial action research inquiry into the effectiveness of ICT in improving the teaching and learning experience in language classes at a Qatari school, TESOL, 2010

[13] R. Barret, 'The Educational Uses of Digital Storytelling', Available at: https://dsresources.pbworks.com /f/Educaional-UsesDS.pdf, 2005, retrieved September 19, 2014

[14] P. Dillenbourg, 'Over-scripting CSCL: The risks of blending collaborative learning with instructional design'. In P. A. Kirschner (Ed). Three worlds of CSCL. Can we support CSCL (pp. 61-91), Heerlen, Open Universiteit Nederland, 2002

[15] C.M., Hung, G., M. Hwang, \& I. Huang. 'A Project-based Digital Storytelling Approach for Improving Students' Learning Motivation, Problem-Solving Competence and Learning' Achievement. Educational Technology \& Society, Vol. 15 (4), pp. 368-379, 2012

[16] E., A. Miler, Digital Storytelling. A Graduate Review, Master of Arts, University of Northern Iowa, August, 2009

[17] Seven things you should know about Digital Storytelling. Available at: https://net.educause.edu /ir /library/pdf /ELI7021.pdf, retrieved January 4, 2015
[18] C., G. Signes, 'Digital Storytelling and Multimodal Literacy in Education', Porta Linguarum, Vol. 22, junio 2014, pp. 237-250, 2014

[19] P., Yuksel, B. Robin and S. McNeil, 'Educational uses of digital storytelling all around the world'. In M. Koehler \& P. Mishra (Eds.), Proceedings of Society for Information Technology \& Teacher Education International Conference 2011 (pp. 12641271). Chesapeake, VA: AACE, 2011

[20] S. Denning, The Springboard: How Storytelling Ignites Action in Knowledge-Era Organizations. Boston: Butterworth Heinemann, 2001

[21] D. D. Howell and D. K. Howerll, Digital Storytelling: Creating an eStory. Worthington $\mathrm{OH}$ : Linworth Publishing, 2003

[22] D. H. Jonassen, 'Designing research-based instruction for story problems'. Educational Psychology Review, Vol. 15 (3), pp. 267296, 2003 http://dx.doi.org/10.1023/A:1024648217919

[23] J. McDrury and M. Alterio, 'Achieving reflective learning using storytelling pathways'. Innovations in Education and Teaching International, Vol. 38 (1), pp. 63-73, 2001 http://dx.doi.org/10.1080/ 147032901300002864

[24] C. A. Mellon, Digital Storytelling: 'Effective learning through the internet'. Education Technology, Vol. 39 (2), pp. 46-50, 1999

[25] M. Heo, 'Digital storytelling: An empirical study of the impact of digital storytelling on pre-service teachers' self-efficacy and dispositions towards educational technology'. Journal of Educational Multimedia and Hypermedia, Vol. 18 (4), pp. 405-428, 2009

[26] D., Meadows, Digital storytelling: Research -based practice in new media. Visual Communication, Vol. 2, pp. 189-193 http://dx.doi.org/10.1177/1470357203002002004

[27] A. Sadik, 'Digital storytelling: A meaningful integrated approach for engaged student learning'. Educational Technology Research, Vol. 56, pp. 487-506, 2008 http://dx.doi.org/10.1007/s11423-0089091-8

[28] R. M. Bottino, and E. Robotti, 'Transforming classroom teaching and learning through technology: Analysis of a case study'. Educational Technology \& Society, 10(4), 174-186, 2007

[29] S. K. Chung, 'Digital storytelling in integrated arts education'. The International Journal of Arts Education, 4(1), 33-50, 2006

[30] L. Malita, and C. Martin, 'Digital Storytelling as web passport to success in the $21^{\text {st }}$ Century'. Procedia - Social and Behavioral Sciences, Vol. 2 (2), pp. 3060-3064, 2020

[31] L. Cohen, and L. Manion, Research methods in Education, Athens: Metehmio, 2000.

\section{AUTHORS}

M. Batsila., M.Sc., M. Ed., and Doctoral Research Student, The Open University, Walton Hall, Milton Keynes, United Kingdom, MK7 6AA (e-mail: marbatsila@ gmail.com).

Ch. Tsihouridis., M.Sc., Ph.D., and Post Doctoral Research student, Department of Special Education, University of Thessaly, Argonafton \& Filellinon 8221, Volos, Greece (e-mail: hatsihour@uth.gr).

Submitted 15 December 2015. Published as resubmitted by the authors 23 February 2016. 